\title{
PENDAPAT IMAM MÂLIK BIN ANAS TENTANG KHULU‘ DAN RELEVANSINYA DENGAN HUKUM PERKAWINAN DI INDONESIA
}

\author{
Ahmad Hoyir \\ Peneliti CESRAS Bandung Jawa Barat \\ E-mail: hoyirahmad19@gmail.com
}

\begin{abstract}
In the discussion of khulu', Imam Mâlik bin Anas argued that khulu' and thalaq are similar. This understanding is caused by a difference of opinions among the scholars. In this case, the verdict delivered by the Bandung Islamic Court in Case Number: 2878/ Pdt.G/2010/PA.Bdg has compatibility with the opinion of Imam Mâlik. In its verdict, the court of Religious Bandung was likening khul'u and thalaq, and set it as thalaq ba'in, so the iddah which fell on women in khulu' is three times qurû", and women have to return the part of dowries to the husband. This paper attempts to explain khulu' according to Imam Mâlik and compliance with laws and regulations.
\end{abstract}

\begin{abstract}
Abstrak
Dalam pembahasan khulu', Imam Mâlik bin Anas berpendapat bahwa khulu' dan thalaq adalah sesuatu yang sama. Pemahaman ini menimbulkan perbedaan pendapat dikalangan para ulama. Dalam hal ini, putusan yang disampaikan Pengadilan Agama Bandung dengan perkara nomor: 2878/Pdt.G/2010/PA.Bdg memiliki kesesuaian dengan pendapat Imam Mâlik. Dalam putusannya, pengadilan Agama Bandung mempersamakan khulu' dengan thalaq, dan menetapkan thalaq yang dijatuhkan pada perempuan yang di khulu' adalah thalaq ba'in, sehingga iddah yang jatuh pada perempuan yang di khulu' adalah tiga kali qurû", serta perempuan harus mengembalikan sebagian maharnya pada suami. Tulisan ini mencoba untuk menerangkan Khulu' menurut Imam Mâlik dan kesesuaiannya dengan peraturan perundang-undangan yang terkait dengan perkawinan.
\end{abstract}

Kata kunci:

suami, isteri, khulu', thalaq

\section{A. Pendahuluan}

Perkawinan merupakan bagian dari syari'at Islam yang menyantuni kebutuhan hidup manusia secara berkelanjutan bergenerasi dengan sebaik-baiknya. Setiap pasangan suami isteri sudah barang tentu menginginkan keluarga sakinah mawaddah wa rahmah, namun kehidupan suami isteri adakalanya berlangsung dengan tentram dan damai, namun tidak jarang juga timbul perselisihan sehingga tidak tampak keharmonisan dalam keluarga, bahkan sulit diselesaikan dengan baik dan damai yang berujung pada perceraian.
Perceraian ialah penghapusan perkawinan dengan putusan hakim, atau tuntutan salah satu pihak dalam perkawinan. ${ }^{1}$

Sesungguhnya Islam tidak melarang perceraian, namun sangat dibenci oleh Allah SWT. Hal ini terbukti pada isyarat Rasulullah SAW, bahwa thalaq atau perceraian adalah perbuatan halal yang paling dibenci oleh Allah.

$$
\begin{aligned}
& \text { عن ابن عمررضي الله عنهما قال: قال رسول الله صلى الله }
\end{aligned}
$$

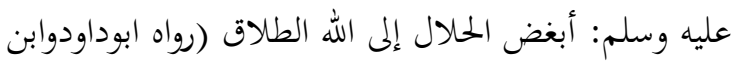

$$
\begin{aligned}
& \text { وماجه, وصحه والحكم, ورجع أبوحاتم إرساله) }
\end{aligned}
$$

${ }^{1}$ Subekti, Pokok-pokok Hukum Perdata (Jakarta: PT. Intermasa. 2003), hlm. 42. 
Dari Ibnu Umar, bahwa Rasulullah SAW bersabda: "Perbuatan halal yang paling dibenci Allah ialah cerai". (Riwayat Abu Dawud dan Ibnu Majah. Hadits Shahih menurut Hakim. Abu Hatim lebih menilainya Hadits Mursal) ${ }^{2}$

Isyarat Rasulullah SAW di atas menunjukan bahwa thalaq atau perceraian, merupakan alternatif terakhir, sebagai pintu darurat yang boleh ditempuh apabila batera rumah tangga tidak lagi dapat dipertahankan keutuhan dan kesinambungannya. Maka pada saat-saat seperti itu, Islam membolehkan penyelesaian satu-satunya yang terpaksa harus ditempuh.

Jika ketidaksinambungan itu datang dari pihak suami, maka ditangannya terletak thalaq yang merupakan salah satu haknya. Dan jika ketidaksinambungan itu datang dari pihak isteri, maka Islam membolehkan menebus dirinya dengan jalan khulu', yaitu mengembalikan mahar kepada suaminya guna mengakhiri ikatan sebagai suami isteri. ${ }^{3}$

Oleh karenanya, agama Islam memberikan hak yang sama (musâwah) dalam melakukan pilihan diantara suami atau isteri untuk tetap melanjutkan pernikahannya atau melepaskannya, mana yang paling baik bagi hubungan mereka. Namun pilihan mana yang akan diambil keduanya, merupakan jalan terbaik. Karena itu perlu diproses secara baik pula. Pertimbangan-pertimbangan yang lebih mendasar, merupakan argumen yang sah bagi isteri untuk mengajukan khulu' kepada suaminya, bukan sekedar argumen hawa nafsu belaka. ${ }^{4}$

Terhadap permasalahan khulu', AlQuran dan Al-Sunnah hanya berbicara yang masalah prinsip, maksudnya hanya menyangkut kebolehan terjadinya khulu' tanpa menjelaskan persoalan-persoalan hukum yang lainnya. Hal tersebut dapat dilihat dalam AlQuran surat Al-Baqarah ayat 229:

\footnotetext{
${ }^{2}$ Ibnu Hajar Atsqalani, Tarjamah Hadits Bulughul Maram (Bandung: Gema Risalah Press. 1994), hlm. 359.

${ }^{3}$ Sayyid Sabiq, Fikih Sunnah (Bandung: Al-Ma'arif. 1980), jilid. III, hlm. 99.

${ }^{4}$ Ayat Dimyati dan Sar'an, Hadits Ahkam Keluarga (Bandung: t.pn. 2008), hlm. 112.
}

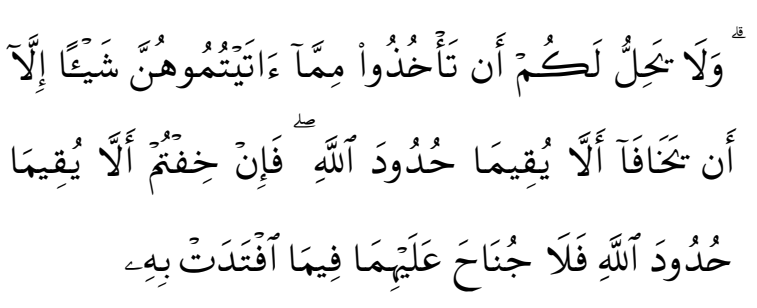

Tidak halal bagi kamu mengambil kembali sesuatu dari yang telah kamu berikan kepada mereka, kecuali kalau keduanya khawatir tidak akan dapat menjalankan hukum-hukum Allah. jika kamu khawatir bahwa keduanya (suami isteri) tidak dapat menjalankan hukum-hukum Allah, Maka tidak ada dosa atas keduanya tentang bayaran yang diberikan oleh isteri untuk menebus dirinya.

\section{B. Pengertian dan Dasar Hukum Keberada- an Khulu'}

1. Pengertian Khulu'

Kata khulu" خلع berasal dari kata "خلع", kata حلع apabila ditinjau dari segi bahasa berarti النزع yakni "mencabut”, karena suami isteri merupakan pakaian bagi yang lainnya. ${ }^{5}$

Rahmat Hakim menegaskan bahwa khulu' yang dibenarkan hukum Islam tersebut berasal dari rangkaian kata "خلع الثواب" artinya "meninggalkan pakaian". Sebab di dalam Al-Quran memberikan nama bagi suami, isteri sebagai pakaian bagi lawannya, artinya suami sebagai pakaian isteri, sebaliknya isteri sebagai pakaian suami. ${ }^{6}$

Khulu' dinamakan juga "tebusan", oleh karena itu isteri menebus dirinya dari suaminya dengan mengembalikan apa yang pernah diterimanya.?

Menurut ahli fiqh sebagaimana diungkapkan oleh Sayyid Sabiq, khulu' adalah isteri memisahkan diri dari suaminya dengan ganti rugi kepadanya. ${ }^{8}$ Adapun makna khulu' menurut istilah, Al-Jaziry menyatakan bahwa ke empat madzhab mempunyai rumusan definisi masing-masing sebagai berikut: ${ }^{9}$

${ }^{5}$ Aliy As'ad, Fathul Mu'in (Jogyakarta: Menara. 1979), hlm. 120.

${ }^{6}$ Rahmat Hakim, Hukum Perkawinan Islam (Bandung: Pustaka Setia. 2002), hlm. 171.

${ }^{7}$ Slamet Abidin dan Aminuddin, Fikih Munakahat II (Bandung: Pustaka Setia. 1999), hlm. 86.

${ }^{8}$ Sayyid Sabiq, Fikih Sunnah, jilid VIII, hlm. 100.

${ }^{9} \mathrm{Al}-J a z i r y, 1989, \mathrm{hlm} .304$. 
Ulama Hanâfiyah menyatakan bahwa khulu' adalah:

$$
\begin{aligned}
& \text { الحلع هو إزالة ملك النكاح المتوفقة على قبول المرأة بلفظ } \\
& \text { الخنع أو ما في معناه }
\end{aligned}
$$

Khulu' adalah hilangnya pemilikan terhadap pernikahan yang telah disepakati dengan penerimaan seorang perempuan terhadap lafazh khulu' atau kata lain yang semakna.

Ulama Mâlikiyah menuturkan bahwa khulu' ialah:

$$
\text { الخلع شرعا هوالطلاق بعوض }
$$

Khulu' menurut syara' adalah thalaq dengan tebusan.

Ulama Syafî'iyah berpendirian bahwa khulu' adalah:

$$
\text { متوفرة فيه الشروط شور اللفظ الدال على الفراق بين الزوجين بعوض }
$$

Khulu' menurut syara' ialah lafazh yang menunjukkan adanya perceraian antara suami isteri dengan suatu tebusan yang memenuhi syarat yang telah ditentukan.

\section{Dasar Hukum Khulu'}

Kehidupan suami isteri hanya bisa tegak kalau ada dalam ketenangan, dan masingmasing pihak menjalankan kewajibannya dengan baik. Tetapi ada kalanya terjadi suami membenci isteri atau isteri membenci suami. Kebencian itu terkadang semakin membesar, perpecahan semakin sangat, penyelesaiannya pun menjadi sulit. Maka pada dasar itu, Islam membolehkan penyelesaian satu-satunya yang harus ditempuh. Jika kebencian adanya pada pihak isteri maka Islam membolehkan menebus dirinya dengan jalan khulu'.

Dasarnya firman Allah SWT dalam Al-Quran surat Al-Baqarah, ayat 229:

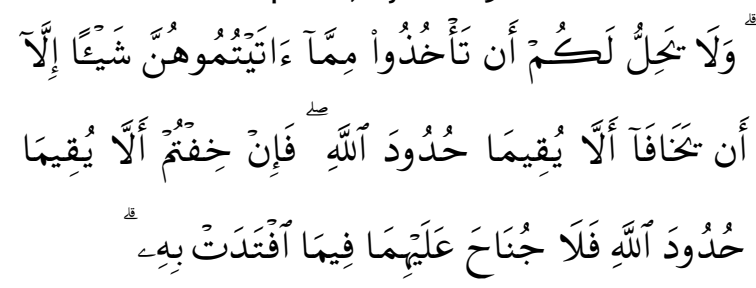

Tidak halal bagi kamu mengambil kembali sesuatu dari yang telah kamu berikan kepada mereka, kecuali kalau keduanya khawatir tidak akan dapat menjalankan hukum-hukum Allah. jika kamu khawatir bahwa keduanya (suami isteri) tidak dapat menjalankan hukum-hukum Allah, Maka tidak ada dosa atas keduanya tentang bayaran yang diberikan oleh isteri untuk menebus dirinya. ${ }^{10}$

Serta hadits Nabi Muhammad SAW:

$$
\begin{aligned}
& \text { عن مالك عن يميى بن سعيد عن عمرة بنت عبدالرحمن اها }
\end{aligned}
$$

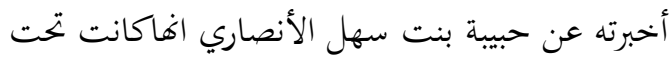

$$
\begin{aligned}
& \text { ثابت بن قيس بن شماس وان رسول الله صلى الله عليه }
\end{aligned}
$$

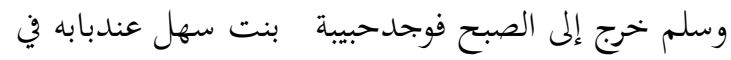

$$
\begin{aligned}
& \text { الغلس فقال لها رسول الله صلى الله عليه وسلم من هذه إنه }
\end{aligned}
$$

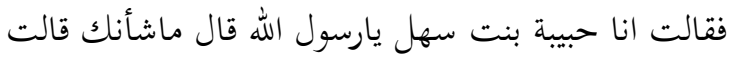

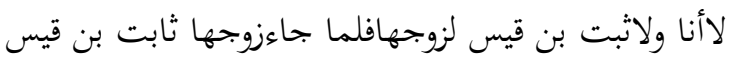

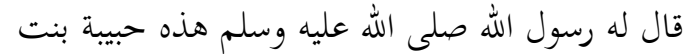

$$
\begin{aligned}
& \text { سهل قدذكرت ماشاء الله ان تذكر فقالت حبيبة يارسول صله } \\
& \text { الله كل ماأعطاني عندي فقال رسول الله صلى الله عليه }
\end{aligned}
$$

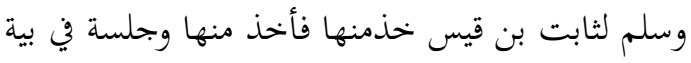

$$
\begin{aligned}
& \text { أهلها. }
\end{aligned}
$$

Mâlik dari Yahya bin Sa'id dari Amarah binti 'Abdul al-Rahmân, sesungguhnya aku memberitakannya dari Habibah binti Sahal alAnsharî. Sesungguhnya Habibah itu isteri Tsâbit bin Qays bin Syamms. Adapun Rasulullah saw. baru keluar dari (masjid) selesai melaksanakan shalat shubuh. Sedangkan Habibah binti Sahal berada di dekat pintu rumah Rasul. Kemudian Rasulullah menegurnya: Siapakah ini? la menjawab: "Aku Habibah binti Sahal wahai Rasulullah". Rasul bertanya lagi, apa maksud kedatanganmu? la menjawab: "Bukan saya, tapi Tsâbit sudah bukan suamiku", ketika suaminya (Tsâbit bin Qays) datang, Rasul bersabda kepada suaminya: "Semoga Allah menghendaki apa yang ia ceritakan"."

\footnotetext{
${ }^{10}$ Nandang Burhanudin, Tafsir Al-Burhan (Edisi AlAhkam) (Bandung: CV Media Fitrah Rabani. 2010), hlm. 81.

${ }^{11}$ Malik bin Anas, Almuwaththa (Beirut: Dâr AlFikr. t.th.), hlm. 1174.
} 


\section{Syarat dan Rukun Khulu*}

1. Syara-Syarat Khulu'

a. Syarat bagi isteri yang mengajukan khulu'

Para ulama madzhab sepakat bagi isteri yang mengajukan khulu' kepada suaminya, harus memenuhi syarat-syarat tertentu, sebagaimana yang diungkapkan oleh Muhammad Jawwâd Mugniyyah sebagai berikut:

1) Baligh;

2) Berakal sehat;

3) Tidak sâfih (idiot), kecuali ada izin dari walinya.

b. Syarat bagi suami yang melakukan khulu'

1) Baligh;

2) Berakal;

3) Tidak safih (idiot). ${ }^{12}$

Kemudian syarat bagi pasangan suami is-teri untuk bisa melakukan khulu' menurut Syaikh Hasan Ayub yaitu:

1) Seorang isteri boleh meminta kepada suaminya untuk melakukan khulu' jika tampak adanya bahaya yang mengancam dan ia merasa takut tidak akan menegakan hukum Allah;

2) Khulu' itu hendaknya dilakukan sampai selesai tanpa dibarengi dengan tindakan penganiayaan yang dilakukan oleh suami. Jika pihak suami yang melakukan penganiayaan, maka ia tidak boleh mengambil sesuatu pun dari isterinya;

3) Khulu' itu berasal dari pihak isteri dan bukan dari pihak suami.

\section{Rukun Khulu'}

Slamet Abidin dan Aminuddin menyatakan bahwa rukun khulu' selain dari adanya isteri yang mengajukan khulu' dan harta yang dipakai untuk khulu' juga harus ada ucapan khulu' ${ }^{13}$

\footnotetext{
${ }^{12}$ Muhammad Jawad Mugniyah, Fikih Lima Madzhab (Jakarta: Penerbit Lentera. 2010), hlm. 78.

${ }^{13}$ Slamet Abidin dan Aminuddin, Fikih Munakahat II. hlm. 89-92.
}

\section{D. 'iwadl Dalam Khulu'}

Berkenaan dengan besar 'iwadl yang lebih kecil atau lebih besar dari mahar yang di-berikan suami kepada isteri, para ulama berbeda pendapat sebagaimana dikemukakan oleh Sayyid Sabiq yang terbagi pada dua pendapat:

Pendapat pertama menyatakan bahwa tidak mengapa mengembalikan semua atau sebagian mahar kepada suaminya, dengan kata lain pembayaran 'iwadl boleh kurang atau lebih dari harga mahar. Pendapat kedua menyatakan bahwa suami tidak boleh menerima 'iwadl dari isteri lebih dari mahar yang diberikannya dulu. ${ }^{14}$

Adapun mengenai syarat dalam 'iwadl, Al-Jaziri menjelaskan mengenai syarat 'iwadl yang telah disepakati oleh para ulama madzhab, adalah sebagai berikut:

a. 'iwadl harus merupakan sesuatu yang ada nilainya;

b. 'iwadl harus merupakan barang yang suci, halal dan layak dimanfaatkan, artinya bukan barang yang najis atau haram;

c. Barang yang dijadikan 'iwadl tersebut, bukanlah merupakan barang hasil gasab atau barang yang didapat dari cara yang menyimpang dari aturan syari'at. ${ }^{15}$

\section{E. Sighat Khulu'}

Para fuqaha berpendapat bahwa dalam khulu' harus diucapkan dengan kata khulu' (خلع), atau lafal yang terambil dari khulu'. Atau bisa juga kata lain yang seperti dengannya, seperti (مبارأة) sama dengan melepas diri, dan fidyah sama dengan tebusan. Jika tidak menggunakan khulu' atau yang seperti dengannya, misalnya suami berkata, "engkau terthalaq" sebagai imbalan dari barang/uang seharga sekian, lalu isteri menerimanya. Maka perbuatan tersebut termasuk thalaq dengan imbalan harta, bukan termasuk khulu'.

Pendapat Hambali, khulu' dinyatakan sah sekalipun tanpa niat, sepanjang hal itu

\footnotetext{
${ }^{14}$ Sayyid Sabiq, Fikih Sunnah. hlm. 106-107.

${ }^{15} \mathrm{Al}$-Jaziri, t.t, hlm. 315.

${ }^{16}$ Slamet Abidin dan Aminuddin, Fikih Munakahat II. hlm. 92.
} 
diucapkan dengan redaksi yang jelas, misalnya dengan al-khulu' (melepaskan), fasakh dan mufada'ah (penebusan). Akan tetapi mereka mensyaratkan adanya majlis yang satu (berada dalam satu majlis) dan tanpa menggantungkan kepada sesuatu. ${ }^{17}$

Kemudian pendapat Hanafi dan Syafi' $i$ menyatakan bawa khulu' boleh dengan menggunakan redaksi al-bai' (jual beli). Seperti suami mengatakan kepada isterinya: "saya jual dirimu kepadamu dengan harga sekian", lalu isterinya menjawab: "saya beli itu". Begitupun khulu' yang digantungkan dengan sesuatu pilihan (khiyar) dan keterpisahan antara penebusan dan khulu'-nya dalam artian suami isteri berjauhan, madzhab Hanafi membolehkan hal tersebut. Sebagaimana Mâlik yang membolehkan keterpisahan antara suami dan isteri yang melakukan khulu' tidak berpengaruh terhadap keabsahan khulu' ${ }^{18}$

Menurut Mâlik bin Anas, khulu' tidak dibatasi dengan mengucapkan lafazh apapun, sehingga kata fidyah, sulh dan kata mubara'ah dapat dipergunakan dalam khulu'. Kata khulu' dipergunakan apabila seorang isteri meminta untuk melepaskan dirinya sendiri dengan mengembalikan semua harta yang telah diberikan kepadanya.

\section{F. Khulu' dalam Pandangan Mâlik bin Anas 1. Kedudukan Khulu' Menurut Mâlik bin Anas}

Mengenai kedudukan khulu', Mâlik bin Anas berpendapat bahwa khulu' kedudukannya sama dengan thalaq. Pendapat tersebut didukung oleh jumhur fuqaha. Abu Hanifah menyamakan khulu' dengan thalaq dan fasakh secara bersamaan, sedangkan Imam AlSyafi'i hanya menyamakan khulu' adalah fasakh. Pendapat ini juga dikemukakan oleh Ahmad dan Daud. Tetapi dalam pendapat barunya (al-qawl al-jadîd) Imam Al-Syafi‘i menyatakan bahwa khulu' itu thalaq. ${ }^{19}$

\footnotetext{
${ }^{17}$ Muhammad Jawad Mughniyah, Fikih Lima Madzhab. hlm. 463.

${ }^{18}$ Ibid. hlm. 463.

${ }^{19}$ Imam Ghazali Said dan Achmad Zaidun, Bidayatul Mujtahid (Analisis Figh Para Mujtahid) (Jakarta: Pustaka Amani. 2007), hlm. 558.
}

Mâlik bin Anas mengatakan bahwa khulu' adalah thalaq, dengan alasan bahwa fasakh itu tidak lain merupakan perkara yang menjadikan suami sebagai pihak yang kuat dalam pemutusan ikatan perkawinan dan bukan berasal dari kehendaknya. Sedangkan khulu' ini berasal dari kehendak.

Mâlik bin Anas menyatakan bahwa thalaq dalam khulu' sebagai thalaq ba'in. ${ }^{20} \mathrm{Abd}$. Rahmat Ghazali dalam bukunya fikih munakahat mengatakan tentang status perceraian karena khulu', mantan suami tidak berhak merujuknya kembali, oleh karena itu, status perceraian karena khulu' adalah sebagai thalaq ba'in. ${ }^{21}$

\section{Hukum Menjatuhkan Khulu' Menurut Mâlik bin Anas}

Khulu', sebagaimana halnya thalaq merupakan suatu cara yang menyebabkan putusnya ikatan perkawinan antara suami isteri. Dalam hal ini, hukum Islam memberikan jalan kepada isteri yang henghendaki perceraian dengan jalan khulu' kepada suaminya sebagai timbal balik atas dibolehkannya suami untuk menceraikan isterinya dengan jalan thalaq.

Dalam memandang hukum menjatuhkan khulu' Mâlik bin Anas sebagaimana jumhur ulama mengatakan bahwa pada dasarnya khulu' merupakan suatu yang dibolehkan dalam syari'at Islam dengan syarat-syarat dan ketentuan yang berkaitan erat dengan dibolehkannya khulu'. Dasarnya firman Allah SWT dalam Al-Quran surat Al-Baqarah, ayat 229:

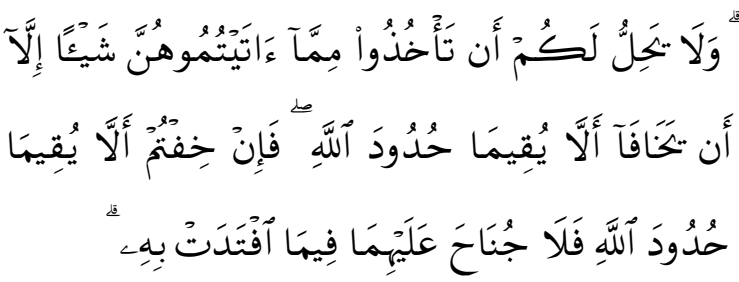

Tidak halal bagi kamu mengambil kembali sesuatu dari yang telah kamu berikan kepada mereka, kecuali kalau keduanya khawatir tidak akan dapat menjalankan hukum-hukum Allah. jika kamu khawatir bahwa keduanya

\footnotetext{
${ }^{20} \mathrm{Al}-\mathrm{Mudawanah}$ al-Kubra, t.t, hlm. 335.

${ }^{21} \mathrm{Abd}$. Rahma Ghazaly, Fikih Munakahat (Jakarta: Kencana Pernanda Media Group. 2003), hlm. 225.
} 
(suami isteri) tidak dapat menjalankan hukum-hukum Allah, Maka tidak ada dosa atas keduanya tentang bayaran yang diberikan oleh isteri untuk menebus dirinya. ${ }^{22}$

$$
\begin{aligned}
& \text { Serta hadits Nabi Muhammad SAW: } \\
& \text { عن مالك عن يهيى بن سعيد عن عمرة بنت عبدالرحمن اهما }
\end{aligned}
$$

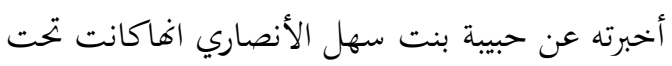

$$
\begin{aligned}
& \text { ثابت بن قيس بن شماس وان رسول الله صلى الله عليه }
\end{aligned}
$$

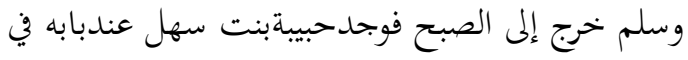

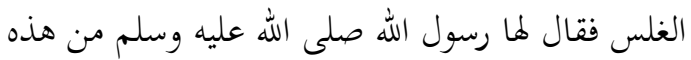

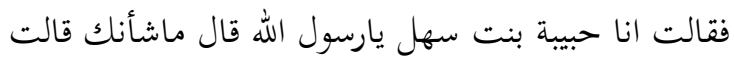

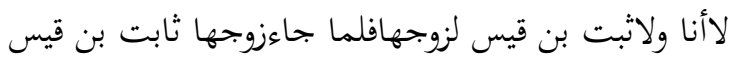

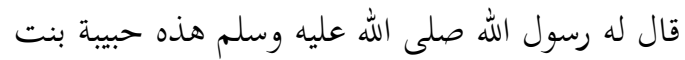

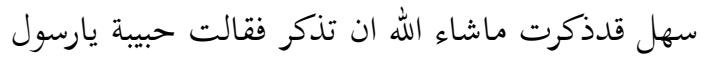

$$
\begin{aligned}
& \text { الله كل مأعطاني عندي فقال رسول الله صلى الله عليه }
\end{aligned}
$$

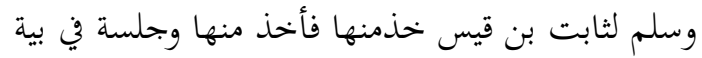

$$
\begin{aligned}
& \text { أهلها. }
\end{aligned}
$$

Mâlik dari Yahya bin Sa'id dari Amarah binti "Abdul al-Rahmân, sesungguhnya aku memberitakannya dari Habibah binti Sahal alAshari. Sesungguhnya Habibah itu isteri Tsâbit bin Qays bin Syamms. Adapun Rasulullah saw. baru keluar dari (masjid) selesai melaksanakan shalat shubuh. Sedangkan Habibah binti Sahal berada di dekat pintu rumah Rasul. Kemudian Rasul menegurnya: Siapakah ini? la menjawab: "Aku Habibah binti Sahal wahai Rasulullah". Rasul bertanya lagi, apa maksud kedatanganmu? la menjawab: "Bukan saya, tapi Tsâbit sudah bukan suamiku”, ketika suaminya (Tsâbit bin Qays) datang, Rasul bersabda kepada suaminya: "Semoga Allah menghendaki apa yang ia ceritakan". 23

\section{Syarat-syarat Kebolehan Terjadinya Khulu' Menurut Mâlik bin Anas}

a. Syarat bagi Isteri yang Mengajukan Khulu'

Para ulama madzhab sepakat bagi isteri yang mengajukan khulu' kepada suaminya, harus memenuhi syarat-syarat tertentu, se-

\footnotetext{
${ }^{22}$ Nandang Burhanudin, Tafsir Al-Burhan. hlm. 81.

${ }^{23}$ Malik bin Anas, Almuwaththa. hlm. 1174.
}

bagaimana yang diungkapkan oleh Muhammad Jawad Mugniyyah sebagai berikut:

1) Baligh;

2) Berakal sehat;

3) Tidak safih (idiot), kecuali ada izin dari walinya. $^{24}$

Mâlik bin Anas dan pengikutnya membolehkan untuki isteri yang mengajukan khulu' dengan keadaan sebagai berikut:

1) Mâlik bin Anas berpendapat bahwa isteri yang sedang sakit keras boleh mengajukan khulu' jika harta tebusannya sebesar warisan dari suaminya. ${ }^{25}$ Sebagaimana Mâlik bin Anas berkata dalam salah satu keterangan yang dikutip oleh Sayyid Sîbiq dalam bukunya figh sunnah, Mâlik bin Anas berkata: "Gantinya wajib diberikan sama besarnya dengan bagian warisan daripadanya". Jika lebih daripada warisan yang seharusnya, maka kelebihannya ini haram dan wajib dikembalikan, thalaqnya jatuh dan keduanya tidak dapat saling mewarisi; ${ }^{26}$

2) Mâlik bin Anas berpendapat bahwa isteri yang masih kecil boleh (dianggap syah) melakukan khulu' apabila khulu' tersebut diajukan oleh ayahnya. Artinya ayah boleh mengajukan khulu' untuk anak perempuannya yang masih kecil. Dengan alasan sebagaimana seorang ayah boleh menikahkan anak perempuannya yang masih kecil. ${ }^{27}$ Ibnu Qasim pernah ditanyai perihal ayah boleh mengajukan khulu' atas anak perempuan yang masih kecil dalam pandangan Mâlik bin Anas: "Mâlik berpendapat bahwa hal itu boleh, tidak boleh bagi seseorang untuk menikahkan seorang perempuan yang masih kecil atau mengajukan khulu' selain ayahnya; ${ }^{28}$

\footnotetext{
${ }^{24}$ Muhammad Jawad Mughniyah, Fikih Lima. hlm. 460.

${ }^{25}$ Slamet Abidin dan Aminuddin, Fikih Munakahat II. hlm. 92.

${ }^{26}$ Sayyid Sabiq, Fikih Sunah. hlm. 114.

${ }^{27}$ Slamet Abidin dan Aminuddin, Fikih Munakahat II. hlm. 91.

${ }^{28}$ Sahnun bin Said, Al-Mudawwanah Al-kubra (t.t.: Dâr Al-Fikr. t.th.), hlm. 240.
} 
3) Mâlik bin Anas menyatakan bahwa isteri yang terlantar yakni yang tidak memiliki washi dan ayah, maka diperbolehkan mengajukan khulu' atas dirinya sendiri sebesar mahar misil; ${ }^{29}$

4) Mâlik bin Anas berpendapat bahwa isteri yang berstatus hamba sahaya (amat) boleh mengajukan khulu' sebagaimana perkataan Mâlik bin Anas: "Khulu' tersebut dibolehkan, dan harta tebusan ditolak apalagi pemilik tidak meridhainya". ${ }^{30}$

b. Syarat bagi Suami yang Mengajukan Khulu'

Adapun mengenai syarat yang mesti dipenuhi oleh suami yang melakukan khulu', sebagai berikut:

1) Baligh;

2) Berakal;

3) Tidak safih (idiot).

Dalam hal ini Mâlik bin Anas berpendapat berkenaan seorang suami dalam keadaan sakit keras, kemudian melakukan khulu' atas isterinya, Mâlik bin Anas berpendapat hal tersebut dibolehkan sebagaimana diterangkan oleh Imam Sahnun dalam kitabnya Al-Mudawwamah Al-Kubrâ sewaktu beliau ditanya perihal seorang wanita yang melakukan khulu' dengan menyerahkan tebusan atas permintaannya yang sedang sakit keras, Mâlik bin Anas menjawab: "Hal itu dibolehkan dan bagi si isteri dapat memperoleh bagian warisan andai suaminya meninggal, akan tetapi bagi suami tidak mendapat warisan andai isterinya meninggal duluan". ${ }^{31}$

c. Syarat Besar dan Sifat 'iwadl dalam Khulu

Berkenaan dengan kadar atau besar 'iwadl khulu' yang dikeluarkan isteri terhadap suaminya, Imam Mâlik, Syafi'i dan golongan fuqaha menyatakan bahwa besar 'iwadl bo-

\footnotetext{
${ }^{29}$ Slamet Abidin dan Aminuddin, Fikih Munakahat II. hlm. 92.

${ }^{30}$ Sahnun bin Said, Al-Mudawwanah Al-kubra. hlm. 240.

${ }^{31}$ Ibid. hlm. 241.
}

leh lebih besar atau kurang dari mahar yang dulu diberikan suami pada isterinya. ${ }^{32}$

Sementara itu Mâlik bin Anas menjelaskan tentang isteri yang memberi tebusan kepada suaminya karena beberapa hal sesuai dengan perkataan Mâlik bin Anas yang dikutip oleh Jalaluddin 'Abdul al-Rahman alShuyuthî sebagai berikut:

$$
\begin{aligned}
& \text { عن مالك عن نفع عن مولاة لصفية بنت أبي عبيد }
\end{aligned}
$$

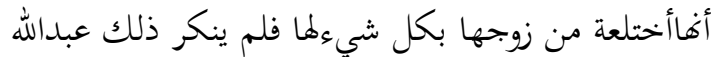

$$
\begin{aligned}
& \text { بن عمر . قال مالك فن المقتديت التى تقتدى من زوجها أنه }
\end{aligned}
$$

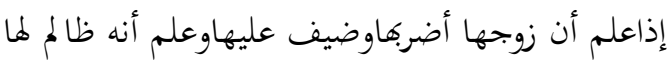

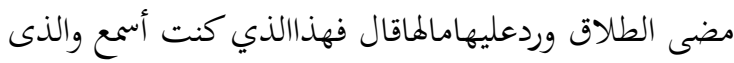

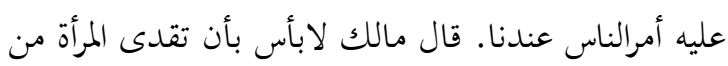

$$
\begin{aligned}
& \text { زوجها بأكثرماأعطاها. }
\end{aligned}
$$

Diberitahukan kepadaku dari Mâlik dan dari Nafi' dari Muwalah tentang Syafiyyah bin Abi 'Abid ketika itu ia telah meminta khulu' kepada suaminya dengan memberikan semua kebenarannya oleh Abdullah bin Umar, Imam Mâlik pun berkata bagi seorang isteri yang memberi tebusan (fidyah untuk khulu') kepada suaminya karena beberapa hal diantaranya bahwa diketahui suami telah berpaling dari isterinya dan telah membuat isteri merasa tersiksa, dan ia juga telah lalai kepada isterinya sehinga ia pun men-thalaqnya dan tidak mau menerima harta yang diberikan isterinya kepadanya sebagai tebusan. Suaminya berkata bahwa yang demikian itu telah aku ketahui sebelumnya dan merupakan suatu perkara yang akan dihadapi oleh manusia, maka Imam Mâlik pun berkata tidak apa-apa (maka Imam Mâlik pun berkata tidak apa-apa) “dibolehkan" seorang isteri memberikan hartanya dengan lebih banyak dari apa yang telah diberikan suami kepada isterinya sebagai tebusan untuk khulu' dari suaminya. ${ }^{33}$

Hal ini dikemukakan pula oleh Imam AlBâzî dalam sarah kitab Al-Muwatha, bahwa

\footnotetext{
${ }^{32}$ Slamet Abidin dan Aminuddin, Fikih Munakahat II. hlm. 89 .

${ }^{33}$ Jalaluddin 'Abdul al-Rahmân Al-Syuyuthi, Tanwirul Hawalikh (Mesir: Maktabat Al-Tabiratul Kubra. t.th.), hlm. 23.
} 
suami boleh mengambil harta yang lebih besar, sedikit atau sama dari apa yang telah diberikan suami pada isterinya. ${ }^{34}$

Kemudian Mâlik bin Anas berpendapat bahwa boleh harta yang tidak diketahui kadar dan wujudnya, serta harta yang belum ada dapat dijadikan sebagai 'iwadl dalam khulu' ${ }^{35}$

d. Akibat Hukum Khulu' menurut Anas bin Mâlik

Mengenai hal ini, hukum yang dimunculkan dari khulu' sebagaimana diungkapkan oleh Ibnu Rusyd dalam kitab Bidâyah Al-Mujtahid edisi Indonesia melipuputi sebagai berikut: ${ }^{36}$

1) Mengikutkan Khulu' dan Thalaq

Mâlik bin Anas dan pengikutnya berpendapat bahwa wanita yang menerima khulu' dari suaminya, maka khulu' tersebut tidak dapat diikuti dengan thalaq, kecuali jika perkataannya bersambung.

Pendapat Mâlik bin Anas diungkapkan dalam kitabnya Al-Muwatha, yang berbunyi sebagai berikut:

$$
\begin{aligned}
& \text { قال مالك إذااقتدت المرأة من زوجها بشيء على أن } \\
& \text { يطلقها فطلقها طلاقا متتابعا نسقافذالك ثابت عليه } \\
& \text { فإنكان بين ذالك صمات فما أثبعه بعد الصمات فليس } \\
& \text { بشيء. }
\end{aligned}
$$

Mâlik berpendapat bahwa apabila seorang isteri menebus dirinya dari suami dengan sesuatu supaya suami menthalaqnya, kemudian suami menthalaqnya secara berturut tanpa ada pemisah, maka hal ini berlaku baginya, akan tetapi apabila ada diam dalam thalaq tersebut, maka thalaq yang dijatuhkan setelah diam tidak dapat mengikuti thalaq sebelumnya dan tidak dianggap. ${ }^{37}$

\footnotetext{
${ }^{34}$ Malik bin Anas, Almuwaththa. hlm. 104.

${ }^{35}$ Slamet Abiddin dan Aminuddin, Fikih Munakahat II. hlm. 89 .

${ }^{36}$ Ibnu Rusy, Bidayah Al-Mujtahid, 2007, hlm. 560561.

${ }^{37}$ Malik bin Anas, Almuwaththa. hlm. 1123.
}

2) Meruju' bekas isteri di Khulu' pada masa iddah

Dalam masalah ini, jumhur ulama menyatakan bahwa tidak boleh melakukan ruju' setelah khulu', karena meskipun khulu' itu bentuk thalaq, namun termasuk thalaq ba'in yang tidak memberikan kemungkinan untuk rujuk. ${ }^{38}$

3) iddah isteri yang di Khulu'

Dalam menentukan iddah isteri yang di khulu' ini Mâlik bin Anas mengemukakan dalam kitab Al-Muwaththonya. iddah isteri yang di khulu' adalah sama dengan iddahnya isteri yang di thalaq, yaitu tiga kali qurû', karena Mâlik bin Anas berpendapat bahwa khulu' itu sama dengan thalaq. Sesuai dengan yang diriwayatkan oleh beliau menyatakan:

$$
\text { وابن شن مالك أنه بلغه أن سعيدبن المسيب وسليمان بن يسار }
$$

Dari Mâlik bahwa sesungguhnya telah sampai kepadanya, bahwa Sa'id Ibnal Musayyab, Sulayman bin Yasar dan Ibnu Syihâb, mereka semua berkata: iddahnya wanita yang di khulu' itu sama seperti iddahnya wanita yang di thalaq, tiga kali qurû'. ${ }^{39}$

\section{G. Analisis terhadap Kesesuaian Khulu menurut Mâlik bin Anas terhadap Putu- san Gugat Cerai di Lingkungan Pengadi- lan Agama Bandung Nomor: 2878/Pdt- $. G / 2010$}

Terdapat kesesuain khulu' menurut Mâlik bin Anas dengan Putusan Gugat Cerai di lingkungan Peradilan Agama Bandung Nomor: 2878/Pdt.G/2010, namun ada beberapa hal yang tidak sesuai, diantaranya sebagai berikut:

\section{Masa iddah}

Dalam menentukan iddah isteri yang di khulu' ini Mâlik bin Anas mengemukakan dalam kitab Al-Muwathanya. iddah isteri yang

\footnotetext{
${ }^{38}$ Amir Syaripuddin, Hukum Perkawinan Islam di Indonesia (Jakarta: Pernanda Media. 2007), hlm. 240.

${ }^{39}$ Malik bin Anas, Almuwaththa. hlm. 1123.
} 
di khulu' adalah sama dengan iddahnya isteri yang di thalaq, yaitu tiga kali qurû', karena Mâlik bin Anas berpendapat bahwa khulu' itu sama dengan thalaq.

Dalam Amar Putusan Perkara Nomor: 2878/Pdt.G/2010/PA Bandung ini, seluruh gugatan penggugat dikabulkan, tapi dalam Amar Putusan ini tidak dicantumkan masa iddahnya, sebagaimana dalam tulisan Umar Mansur Syah bahwa dalam Amar Putusan Gugat Cerai dicantumkan masa iddahnya. ${ }^{40}$

Adapun tujuan dengan adanya iddah bagi si isteri (penggugat) yaitu dengan dapat diketahui apakah si isteri telah mengandung dari suami terdahulu, agar ia tidak bimbang mengenai ayah dari anak yang dikandungnya itu, bila si isteri itu akan (ingin) menikah lagi. Firman Allah SWT menegaskan dalam AlQuran surat Al-Baqarah ayat 228:

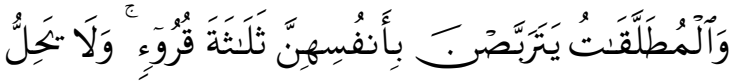

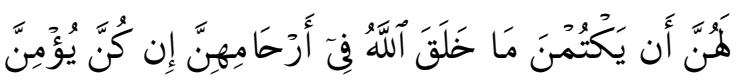

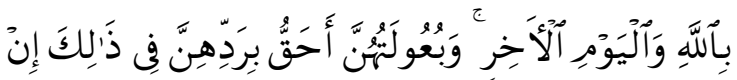

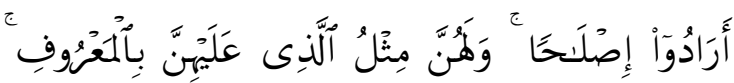

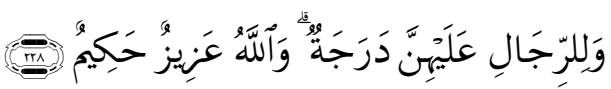

Wanita-wanita yang ditalak handaklah menahan diri (menunggu) tiga kali qurû'. tidak boleh mereka menyembunyikan apa yang diciptakan Allah dalam rahimnya, jika mereka beriman kepada Allah dan hari akhirat dan suami-suaminya berhak merujukinya dalam masa menanti itu, jika mereka (para suami) menghendaki ishlah dan para wanita mempunyai hak yang seimbang dengan kewajibannya menurut cara yang ma'ruf, akan tetapi para suami mempunyai satu tingkatan kelebihan daripada isterinya dan Allah Maha Perkasa lagi Maha Bijaksana.

Pendapat Mâlik bin Anas dan Putusan Gugatan Cerai tidak sesuai, dengan alasan dalam putusan tidak dicantumkan masa iddahnya.

\footnotetext{
${ }^{40}$ Umar Mansur Syah, 1997, hlm. 76.
}

\section{Jumlah 'iwadl atau Beban Perkara yang Dibebankan pada Isteri yang di Khulu'}

Pada masalah ini yang penulis temukan, bawa Mâlik bin Anas tidak menentukan jumlah/ukuran 'iwadl yang harus diberikan kepada suaminya, hanya saja Mâlik bin Anas memberikan keringanan bahwa isteri memberikan 'iwadl atau tebusan untuk suaminya boleh kurang, sama atau lebih dari apa yang telah diberikan oleh suami pada isternya dulu.

Kemudian Amar Putusan Pengadilan Agama Bandung Nomor: 2878/Pdt.G/2010/PA yang membebankan perkaranya pada tergugat (isteri yang meminta khulu') sejumlah Rp. 391.000,- (tiga ratus sembilan puluh satu ribu rupiah).

\section{H. Penutup}

Berdasarkan uraian dan pembahasan di atas yang menyangkut khulu' menurut Mâlik bin Anas dan kesesuaiannya dengan Putusan Gugat Cerai Nomor: 2878/Pdt.G/2010/PA Bandung, yang telah penulis deskripsikan dalam bab-bab sebelumnya, akhirnya penulis dapat menarik kesimpulan di bawah ini.

Khulu' menurut Mâlik bin Anas diartikan sebagai thalaq dengan tebusan ('iwadl) yang dibayar oleh isteri atau yang lainnya, yang bertindak sebagai wali atau bukan atau dengan ucapan khulu' dari suaminya. Khulu' diperbolehkan dengan syarat dikehendaki oleh pihak isteri dan suami tidak memadaratkan terhadap isteri. Hukum kebolehan khulu' menurut Mâlik bin Anas berdasarkan pada Nash Al-Quran dan Al-Hadits dan hukum yang lainnya yang didasarkan pada kemaslahatan.

Kadar 'iwadl dan khulu' Mâlik bin Anas berpendapat boleh kurang, sama bahkan lebih banyak dari apa yang telah suami berikan pada isterinya waktu dulu. Disamping itu pula Mâlik bin Anas berpendapat kadar yang dijadikan 'iwadl atau tebusan boleh dengan barang yang samar. Kedudukan khulu' menurut Mâlik bin Anas adalah thalaq ba'in. Dalam khulu' dapat menimbulkan akibat hukum lainnya, diantaranya ialah menyangkut ketidakabsahan mengikuti khulu' pada thalaq kecuali apabila bersambung, ketidakbolehan rujuk pada isteri yang telah di khulu'. Kemudian dalam masalah khulu' ini Mâlik bin 
Anas menyatakan iddahnya isteri yang di khulu' adalah tiga kali qurû'.

Kemudian dalam hal kesesuaian khulu' menurut Mâlik bin Anas dalam Putusan Gugat Cerai Nomor: 2878/Pdt.G/2010/PA. Bandung, adanya ketidaksinambungan, adanya salah satu satu yang dirugikan, kemudian ingin berpisah, begitupun dalam hal thalaq yang dijatuhkan yaitu thalaq ba'in. Kemudian yang berbeda antara pendapat Mâlik bin Anas dan Putusan Gugat Cerai Nomor: 2878/Pdt.G/2010/PA Bandung, yaitu tidak dicantumkannya masa iddah.

\section{Daftar Pustaka}

Abidin, Slamet dkk. 1999. Fikih Munakahat II. Bandung: Pustaka Setia.

As'ad, Aliy. 1979. Fathul Mu'in. Jogyakarta: Menara.

Atsqalani, Ibnu Hajar. 1994. Tarjamah Hadits Bulughul Maram Bandung: Gema Risalah Press.

Burhanudin, Nandang. 2010. Tafsir Al-Burhan (Edisi Al-Ahkam). Bandung: CV Media Fitrah Rabani.
Dimyati, Ayat dkk. 2008. Hadits Ahkam Keluarga. Bandung: t.pn.

Ghazaly, Abd. Rahma. 2003. Fikih Munakahat. Jakarta: Kencana Pernanda Media Group.

Hakim, Rahmat. 2002. Hukum Perkawinan Islam. Bandung: Pustaka Setia.

Mâlik bin Anas. t.th. Almuwaththa. Beirut: Dâr Al-Fikr.

Mugniyah, Muhammad Jawad. 2010. Fikih Lima Madzhab. Jakarta: Penerbit Lentera.

Sabiq, Sayyid. 1980. Fikih Sunnah. Bandung: Al-Ma'arif.

Sahnun bin Said. t.th. Al-Mudawwanah Alkubra. t.t.: Dâr Al-Fikr.

Said, Imam Ghazali dkk. 2007. Bidayatul Mujtahid (Analisis Fiqh Para Mujtahid) Jakarta: Pustaka Amani.

Syaripuddin, Amir. 2007. Hukum Perkawinan Islam di Indonesia (Jakarta: Pernanda Media.

Syuyuthi, Jalaluddin 'Abdul al-Rahmân, Al-. t.th. Tanwirul Hawalikh. Mesir: Maktabat Al-Tabiratul Kubra. 